\title{
BRINGING THE EARTH TO LIFE
}

\author{
GEOSCIENCE IS A CHALLENGING SCIENCE TO TEACH. IT INVOLVES \\ PROCESSES THAT OCCUR OVER HUGE SCALES OF TIME AND SPACE, \\ AND MUCH OF ITS SUBJECT MATTER IS DEEP UNDERGROUND. \\ DR GLENN DOLPHIN, OF THE UNIVERSITY OF CALGARY IN CANADA, IS \\ COMMITTED TO TACKLING THIS CHALLENGE, THROUGH CONNECTING \\ TEACHERS AND STUDENTS WITH AUTHENTIC RESEARCH EXPERIENCES
}

\section{THE ART OF TEAGHING}

As you will know, effective teaching and learning is not just about the presenting and memorising of facts. To convey a proper understanding of the world, teaching needs to be engaging, interesting and accessible. What teaching techniques engage you? What makes learning memorable for you? What makes you excited about a subject? What makes you want to learn more?

Geoscience, or Earth science, does not always get the limelight in the same way as other sciences, such as astronomy or ecology.

However, it is essential to our understanding of the world, and at the heart of many societal issues. Dr Glenn Dolphin, Tamaratt Teaching Professor in the Department of Geoscience at Canada's University of Calgary, has introduced some novel teaching methods to help geoscience get the recognition it deserves.

\section{GEOSCIENCE'S PUBLIC IMAGE}

"Earth science is a very neglected science, and professional Earth scientists are retiring faster than they can be replaced," says Glenn. He believes a key part of this is that it is not always taught effectively, and many students don't see it for the fascinating subject area that it is. Geoscience has a key role in tackling humanity's most pressing problems: climate change, extraction of energy and mineral resources, and access to clean air and water. Glenn is passionate in his belief that geoscience is a subject we should be paying more attention to.

New talented and enthusiastic Earth scientists - and Earth science teachers - are sorely needed. How can Earth science teachers be taught to teach well? "Traditional teaching methods, such as lectures and essays, are not nearly as effective as evidence-based approaches," says Glenn. "This is where the model-based approach and authentic research experiences come in."

\section{MODELS TO UNDERSTAND THE EARTH} What's more engaging: an essay about tectonic plates, or a physical model of them in action? Geoscience is complex, and the processes

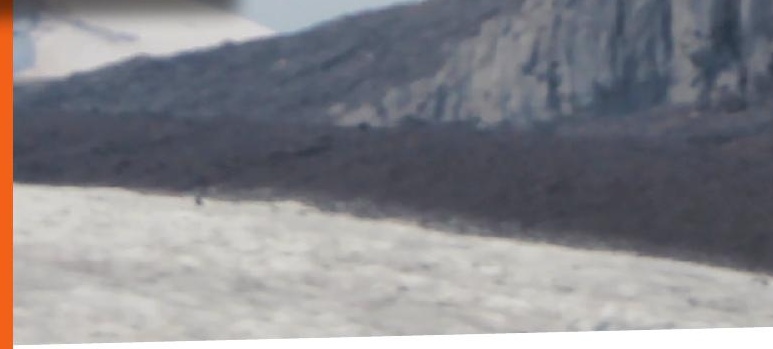

it studies happen at a far grander scale - in terms of both space and time - than we are accustomed to. To help teach this complexity and make the abstract concepts more approachable, physical and virtual models are an invaluable tool.

For instance, virtual outcrop models are one handy device in this arsenal. They are computer-generated 3D models of real-world rock outcrops. Drones capture hundreds or thousands of images of the physical outcrop from every angle, and the software 'stitches' these images together. Students can then explore these outcrops from the comfort of their computers.

\section{GUIDING TEACHERS}

As part of a team of teacher educators, Glenn worked with trainee teachers to address the 


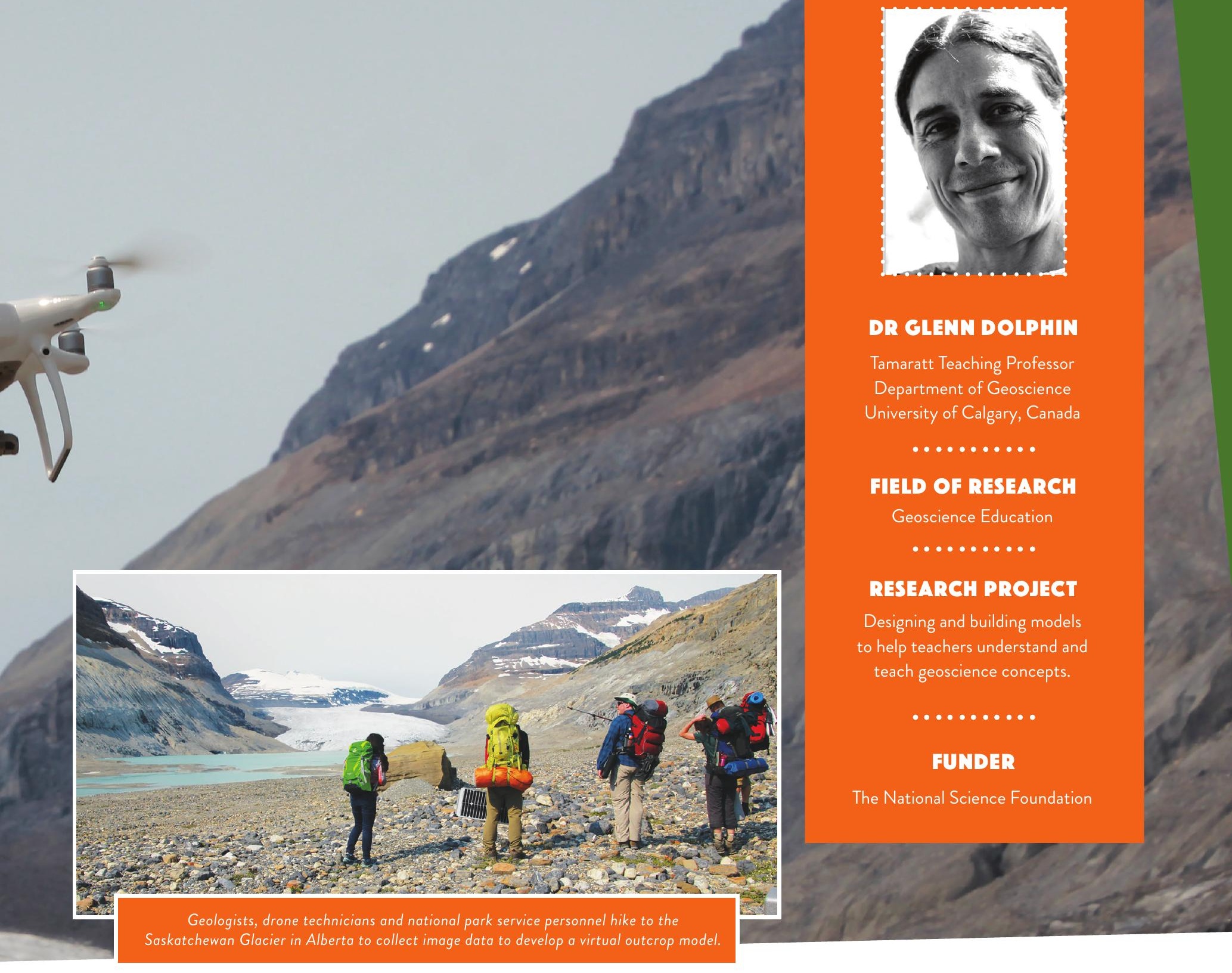

concepts that are difficult to teach. Once teachers had selected a concept, they and Glenn's team researched it and built a model to act as a teaching aid. Teachers were enthusiastic about the research and reported they had learnt a lot from the design-andbuild process.

They presented these models at a science teachers' conference, where other science educators also found them instructive. Many have also been rolled out to real classrooms, to see how successful they are in making the teaching and learning process easier.

Glenn hopes geoscience teachers "will continue to enhance their learning and teaching by continued research and development of models." However, he wants teachers to be reflective as well as ambitious. He adds, "Hopefully, they will also become critical of models they use as many actually pose problems for learning as well as offer solutions."
DRAMA AND BUILDING

Glenn believes that the intersection between science and the humanities should be embraced to make learning as captivating as possible. "I am currently collaborating with the university's drama department to produce a play about four famous female geologists from different time periods," he says. "It will explore their life histories, their research and the role that gender played in their careers."

$\mathrm{He}$ is also working with the architecture department to develop a geological 'time walk'. "It will be a scale model of the history of the Earth, in the form of a path," he says. "People can walk along it and get a sense of the scale of geological time."

Glenn is passionate about looking at the human stories behind science. For him, the history of how scientific knowledge has come to be is as important as the science. Glenn explains, "Demonstrating how science 'fits'
DR GLENN DOLPHIN

Tamaratt Teaching Professor

Department of Geoscience

University of Calgary, Canada

FIELD OF RESEARCH

Geoscience Education

RESEARCH PROJECT

to help teachers understand and

teach geoscience concepts.

FUNDER

The National Science Foundation into the rest of life provides a broader view of how science emerges from researchers' real lives and real passions."

\section{LOOKING TO THE FUTURE}

Glenn hopes that his work will continue to be used by teachers to enhance their knowledge and teaching skills. "These teachers will have contact with thousands of students during their careers," he says. "That is where the big payoff will be. Hopefully, they will bring other teachers along with them on this journey. If others see how successful they are, these teachers become models for future teachers." Inspiring teachers lead to a 'snowballing' change in teaching style.

For the future of geoscience itself, there is a lot of fascinating and important research waiting to be done. There is ample opportunity for entry into the field, especially for those who are passionate about fixing the world's problems. 



\section{HOW DID DR GLENN DOLPHIN BECOME A GEOSCIENTIST?}

WHAT DID YOU WANT TO BE AS A CHILD?

I have wanted to be a geologist ever since I can remember. As a kid, I would keep pretty rocks in a large milk container and would wash and organise them. I often went to rock and mineral shows, bought crystals, and participated in a local rock and mineral club. I was surrounded by very supportive people, especially my dad and several teachers, who really influenced my trajectory into geology.

\section{WHO INSPIRED YOU IN}

\section{YOUR CAREER?}

I have had many inspirations throughout my life. I had an enthusiastic Earth science teacher in ninth grade, and several professors at my local university helped me decide where to study. I had a great mentor when I then studied to become a teacher, after which I went on to teach at my old high school alongside two of my former teachers. These two people were crucial in helping me develop my teaching style, letting me explore alternative methods and helping me get leadership roles. I then got a PhD in science education, guided by many inspirational figures, and even in my current post I have great colleagues who help support my work.

WHAT CHALLENGES HAVE YOU FACED IN YOUR CAREER?

My toughest personal decision was leaving my daughter in New York when I went to work in Calgary. She was nine at the time and I regret missing many moments of her growing up. Professionally, my greatest challenge is getting more 'traditional' geoscientists to consider this kind of work important. It seems 'fluffy' to them because they don't consider it hard science, and I find it difficult when I feel my work is not valued.
WHAT ATTRIBUTES HAVE HELPED YOU BECOME SUCCESSFUL?

I have a lot of energy and passion for what I do, and students can sense that and become passionate themselves. A thankyou note from a student of mine said, "I am studying to be a teacher and feel so enthused after taking your class. Your passion for teaching and creating inspired, engaged learners is truly motivating."

WHAT ARE YOU MOST PROUD OF? I am most proud of my family: three wonderful daughters and my wife, who is more than anyone deserves. My second proudest achievement is a textbook I wrote for one of my geology courses: "Stories in Geology: What we know and how we figured it out." This book helps to fill two gaps in science teaching: the 'process of science', and the role of humanities and history in science.

\section{PATHWAY FROM SCHOOL TO GEOSCIENIIST}

At school, subjects like physics, maths and chemistry are the most desirable for university applications. Geography, computer science or biology are also favoured by some universities. Degrees in geology, geoscience, geophysics or Earth science can all lead to a geoscience career.

Glenn recommends taking every subject you can, even those outside your comfort zone. As well as maths and science, arts and the humanities play a significant part in research and teaching.

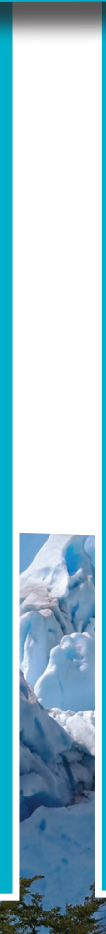

\section{GLENTS TOP TIPS FOR SIUDENTS}

01 - Find your passion and embrace it. Take chances and spend as much time as possible outside of your comfort zone.

02 - Use all your accumulated life experience, even chapters you don't like, to make you who you are.

03 - Be bold, but also understand that our lives are shaped by everyone around us. We can influence the direction of our lives but are never in full control. I find this to be very liberating.
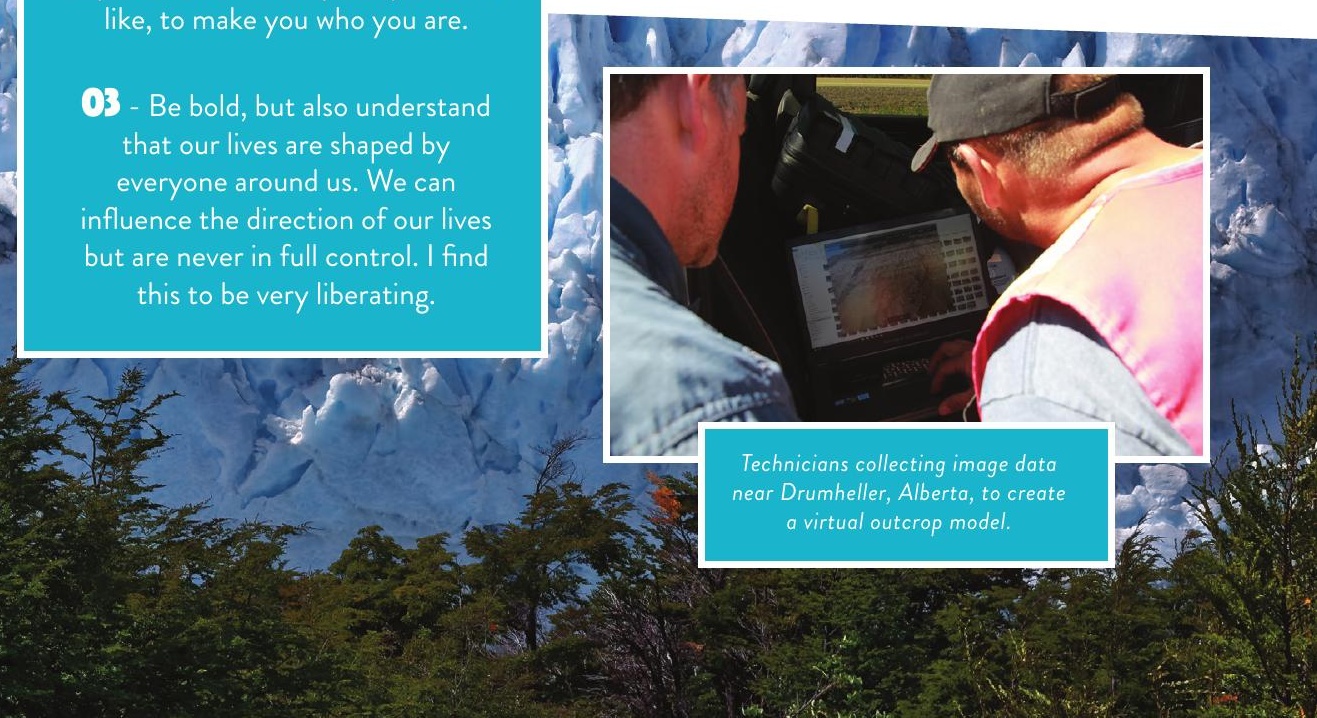